\title{
The Banquet Culture in New Jerusalem, an Aramaic Text from Qumran
}

\author{
Hugo Antonissen
}

\section{1 \\ Introduction}

The Aramaic New Jerusalem text from the caves of Qumran has been preserved in a very fragmentary state on the remains of six manuscripts, $2 Q_{2}$, 4Q554, 4Q554a, 4Q555, 5Q15, and 11Q18, and probably also on the still more fragmentary remains of a seventh manuscript, viz. $1 \mathrm{Q}^{2}{ }^{1}$ The author of the text describes a city with gigantic dimensions and its cult, probably in an eschatological context of some kind. Fragments $13+14$ of $4 Q 554^{2}$ seem to refer to a major reversal in history when it mentions the king of Media (line 15), the kingdom of the Kittim (line 16), Edom, Moab, and the Ammonites (line 18), and Babylon (line 19) on the one hand and the threat to, or oppression of, Israel on the other hand in the form of doing wrong to its descendants (line 20: "your seed), an oppression which probably came to an end (line 16) at a certain moment in history. ${ }^{3}$ The relationship between this major reversal and the description of a planned city that is intended to accommodate and to entertain an enormous amount of people, possibly pilgrims, cannot be established. The text of New Jerusalem as such was composed probably between 175 and 150 BCE. ${ }^{4}$

As one struggles through the imperfectly preserved landscape of the fragments of New Jerusalem, one picks up isolated data. At first sight the relationship between some of these separate data remains unclear. As in other fragmentary texts one can proceed from the data involved to an interpretation of the contents of the text. In order to perceive, through the scattered and isolated data, the contours of the framework in which the text belongs, one can look for a vantage point. From this vantage point, the fragmentary data can be fitted and located in an acceptable presupposed overall contextual pattern. The

1 The translation of the manuscripts as referred to in the present article is based on direct personal research of the photographs concerned unless otherwise stated.

2 Émile Puech, Qumrân grotte 4.XXVII: Textes araméens, deuxième partie: $4 Q 550-575 a, 580-587$, DJD 37 (Oxford: ClarendonPress, 2009), 136-38.

3 Hugo Antonissen, "The Visionary Architecture of New Jerusalem in Qumran," in Qumran und die Archäologie: Texte und Kontexte, ed. Jörg Frey, Carsten Claußen, and Nadine Kessler, wUNT 278 (Tübingen: Mohr Siebeck, 2011), 439-80 (471-78).

4 Puech, DJD 37:100. 
aim of the present article is to argue that the most appropriate vantage point is the Greco-Roman banquet culture shared by the peoples of the Mediterranean world, during the period circa $300 \mathrm{BCE}$ to circa $300 \mathrm{CE}$. The thesis I shall try to support in the present article can be phrased as follows: In the city described in New Jerusalem, the cult is performed both in the form of the traditional Jewish temple cult on the one hand, and by a respectful and pious banquet custom on the other hand. Following Smith, I use the term "Greco-Roman" to refer to this period because the major cultural influences of this time and place were those of the Greeks and later of the Romans, whose culture was largely adapted from that of the Greeks. ${ }^{5}$

It is not the aim of the present article to give an account of an extensive and profound research. As the contents of the text of New Jerusalem have been preserved in a very fragmentary state it is impossible to study meticulously all the aspects, components, and features as well as the habits, customs, and practices of the banquet culture concerned. An inventory of the components of the formal meal in the shape of a banquet should contain at least the following items: invitation, ${ }^{6}$ ranking and arranging of the guests, ${ }^{7}$ both performed by the host, ${ }^{8}$ the role of the symposiarch, ${ }^{9}$ dining rooms with specific accommodation, ${ }^{10}$ posture at the meal, viz. reclining, ${ }^{11}$ a specific order of the meal, which consists of two courses: first deipnon, eating, and second symposion/potos, drinking, ${ }^{12}$

Dennis E. Smith, From Symposium to Eucharist: The Banquet in the Early Christian World (Minneapolis, MN: Fortress Press, 2003), 18-19.

6 Smith, From Symposium to Eucharist, 22-25, 135.

7 Katherine M. D. Dunbabin, The Roman Banquet: Images of Conviviality (Cambridge: Cambridge University Press, 2003), 39; Gil P. Klein, "Torah in Triclinia: The Rabbinic Banquet and the Significance of Architecture," JQR 102 (2012): 325-70 (331-34); Sandra R. Shimoff, "Banquets: The Limits of Hellenization," JSJ 27 (1996): 440-52 (448; "proper protocol"); Smith, From Symposium to Eucharist, 33, 136.

8 Smith, From Symposium to Eucharist, 33.

9 Smith, From Symposium to Eucharist, ${ }_{136-37 .}$

10 Dunbabin, The Roman Banquet, 36-43; Klein, "Torah in Triclinia," 331-34; Marie-Christel Hellmann, L'architecture grecque: 3. Habitat, urbanisme et fortifications (Paris: Picard, 2010), 50; Shimoff, "Banquets: The Limits of Hellenization," 441; Smith, From Symposium to Eucharist, 25-27; Pauline S. Pantel, La cité au banquet: Histoire des repas publics dans les cités grecques (Rome: L'École française de Rome, 1992; repr. in Les Classiques de la Sorbonne 2, Paris: Publications de la Sorbonne, 2011), 304-7.

11 Dunbabin, The Roman Banquet, 11-18; Klein, "Torah in Triclinia," 331-32; Pantel, La cité au banquet, 6, 18, 277; Shimoff, "Banquets: The Limits of Hellenization," 448; Smith, From Symposium to Eucharist, 14-20, 137-38.

12 Dunbabin, The Roman Banquet, 19; Shimoff, "Banquets: The Limits of Hellenization," 44142; Pantel, La cité au banquet, 483; Smith, From Symposium to Eucharist, 27-31. 
separated by a transition, ${ }^{13}$ entertainment, ${ }^{14}$ and "festive joy". ${ }^{15}$ I shall not draw up a complete checklist of the aspects, features, and components of the Greco-Roman banquet culture in order to check meticulously each separate item of the list concerned. Because of the very fragmentary state of the text preserved it is impossible to produce a definite proof of the Euclidian kind that the city as described in New Jerusalem was intended for pilgrims to participate in the performance of the cult in the form of a banquet similar to the Greek banquets on city level.

The train of thought I shall go through in the present article runs as follows. First, I shall discuss the question concerning the character of the city (section II.I). It has been possible to reconstitute one continuous story line, which describes the measuring of the city ground plan and its division by boulevards and streets surrounding compounds with identical constituting modules. Next I shall discuss the matter of couches intended for reclining (section II.II). Thereafter I shall discuss the typological similarity between the compound described in New Jerusalem, viz. an insula, and the "Largest Peristylium" in the city of Alexandria in the third century вСE both made up of banquet rooms (section II.III). Furthermore I shall deal with the contents of fragments of texts related to "eating" and "drinking," and the sacred character of formal banquets (section III). A closer look at some details of the course of a Greco-Roman banquet may even help to solve the mention of "an outer gutter" in connection with the description of banquet rooms in New Jerusalem (section IV). A tiny fragment refers to "rooms of joy", which in my opinion could be connected with the concept of "festive joy," an important feature of the Greco-Roman banquet culture (section v). In relationship to "festive joy," early Jewish texts, which in one way or another can be connected with the contents of New Jerusalem are discussed. The early Jewish texts concerned are Ben Sira, the Letter of Aristeas, the Temple Scroll, the Rule of the Community, the Rule of the Congregation, the Mishnah, and the Tosefta.

In the context of the present article, the early Jewish banquet tradition as dealt with in the aforementioned texts will be taken into consideration in order to check if the early Jewish religious experience is compatible with eating and drinking wine in the Greco-Roman tradition either in a more restricted circle or on a massive scale. Furthermore, I will discuss the level on which the

13 Shimoff, "Banquets: the Limits of Hellenisation", 442; Smith, From Symposium to Eucharist, 28.

14 Shimoff, "Banquets: the Limits of Hellenisation", 442, 446 ("singing", "retelling fables"); Smith, From Symposium to Eucharist, 34-38.

15 Smith, From Symposium to Eucharist, 12, 84-85. 
banquet culture is performed in the city described in New Jerusalem, viz. the city level, and the occasion on which the banquets concerned were performed (section VI). Maybe here the number of thirty-two thousand nine hundred (11Q18) might make some sense. In order to round off the support of the thesis I shall deal with the performance of the banquet culture by pilgrims on the city level (section VII).

In the present article I shall use the term "banquet" as a generic term for the festive consumption of food and drink in the aforementioned Greco-Roman banquet culture. The most general Latin term for the formal festive consumption of food and drink is convivium. The term literally means "living together""It conveys associations of festivity and conviviality."16 Cicero expresses an idealized view of dining when he makes Cato commend the Romans for choosing the term convivium to describe "the reclining of friends at a banquet, because it implies the conjunction of life," in preference to the Greek terms "drinking together" or "eating together," viz. symposion or syndeipnon..$^{17}$ This brings us to the Greek terminology: "The Greeks customarily had two welldefined courses in their banquet. The first course was the deipnon proper, during which the meal of the evening would be eaten. The second course was the symposium (symposion) or drinking party, which would be an extended period of relaxed drinking, during which the entertainment of the evening would be presented."18

\section{Architecture and Reclining}

\subsection{Character of the City}

One of the questions raised by the text of New Jerusalem as preserved concerns the character of the city. In any case one has to keep in mind that the city as described in New Jerusalem is indeed Jerusalem because of the presence of the temple almost in its centre, where one of the central boulevards passes it either on the northern side or on its left: "And the th[ir]d 〈boulevard〉, which

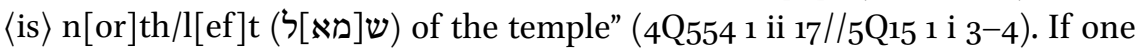
takes into consideration all available information, one is able to conceive a city with a rectangular Hippodamian ground plan, divided by six boulevards

\footnotetext{
16 Dunbabin, The Roman Banquet, 4.

17 Dunbabin, The Roman Banquet, 13.

18 Smith, From Symposium to Eucharist, 27; see also Pantel, La cité au banquet, 4, 483; Pantel discusses the semantic field of the terms deipnon and symposion in a very meticulous way (see general index).
} 


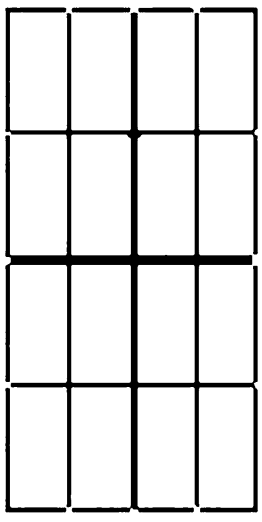

FIGURE 1 Plan of the city in New Jerusalem

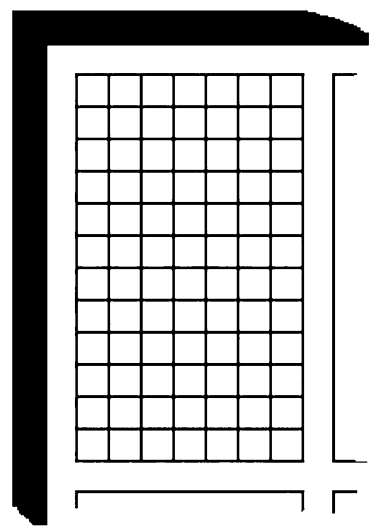

FIGURE 2

Hypothetical ground plan of the north-western rectangle

creating sixteen rectangles by intersecting each other (fig. 1). Each of the sixteen rectangles is divided by intersecting streets creating square compounds (fig. 2).

The text as preserved does not enable one to calculate the number of the square compounds. Each compound, which I call insula, has four gates and consists of sixty identical units all equipped with the same number of couches. This ground plan, built up gridwise on different levels, does not seem to point in the direction of a normal residential way of life on a family basis since not all families have the same number of members. Two other functions of the city itself have been suggested: a vast military camp or a pilgrimage city. ${ }^{19}$ The regular design of the city ground plan in combination with the fortified wall could also be intended for a military purpose. Extension of the holiness to the entire city itself is an argument in favour of a pilgrimage city after a major reversal in history as mentioned above. Indeed, the whole city is covered with white stone: "And all streets of the city [〈were $\rangle$ paved with white stone]" (4Q554 1 ii 22//5Q151 i 6). ${ }^{20}$ On first sight this clause might be simply informative in nature concerning the colour of the material used to cover the streets and probably all the buildings in the city. The presence of "white stone" in an incompletely preserved Neo- or Late Babylonian Marduk hymn (BM 36646) ${ }^{21}$ containing an eulogy of Babylon (lines 4'-14') throws a different light on the meaning of the term "white stone." Just like other precious materials the term is used to glorify the deity, viz. Marduk, in praising his city. ${ }^{22}$ Like in New Jerusalem,

\footnotetext{
19 For a discussion of the three functions, residential, military, or pilgrimage, see Antonissen, "The Visionary Architecture of New Jerusalem in Qumran," 478-79.

$20 \quad$ See also Puech, DJD 37:116.

21 BM $45986+46065+46121+46166$ II 6'-8': Andrew R. George, Babylonian Topographical Texts, OLA 40 (Leuven: Peeters, 1992), 231, with figure 30.30.1.

22 Antonissen, "The Visionary Architecture of New Jerusalem in Qumran," 456-57.
} 
Isaiah (54:11-12), and Tobit (13:16-17), precious materials are enumerated in the eulogy: obsidian, lapis lazuli, white stone, and precious jasper (lines 6'-8'): "Eternal city of privilege [...] spacious treasure house [...] bolt of carnelian obsidian, lapis lazuli, white stone [...] precious jasper like the sea 〈it is〉 lifted $[\ldots]$ as an orchard of fruit its sumptuousness [is inexhaustible (?)] as a floodwave $\langle$ is $\rangle$ its might [exalted] Delightful star of Marduk ... [...] wherever the sun $\langle$ is $\rangle$, its city gate [...] Imgurenlil [...]." This mention of white stone reminds us of other precious stones, mentioned in New Jerusalem, and points to the exalted value of this stone, which in the Babylonian text is related to the deity in a glorifying perspective. Scattered all over the fragments of the manuscripts of New Jerusalem a number of other precious materials are mentioned: דהב (11Q18 10 i 2, 6; 11 4), "gold"; הובץ (11Q18 10 i 5; 12 i 7; 16 i 1), a kind of stone; יהלם (5Q15 22 1), "onyx"; חשמל (4Q554 2 ii 15), "electrum"; כדכוד (4Q554 2 ii 15), "ruby"; ספיר (4Q554 2 ii 15), "sapphire." It seems reasonable to assume that these materials suggest that the gigantic city in its totality is of a divine nature.

\subsection{Reclining and Couches}

A basic and indispensable component of the Greco-Roman banquet culture is the banquet room. In the Greek tradition such a room is called andrōn. In the Greek fashion a typical banquet room-always of a quadrangular shapehad a slightly raised platform along the wall in order to place the (wooden) couches (sing. klinē, pl. klinai) head to toe. ${ }^{23}$ The floor could remain undecorated or covered with cemented pebbles or a mosaic decoration. The couches were arranged along the walls on a continuous masonry ledge, with a table in front of each couch, one or two participants per couch, ${ }^{24}$ "allowing the diners to recline on their left elbows and eat with their right hands." ${ }^{25}$ Reclining is a common feature of the Greco-Roman banquet culture. It was part of an elaborate pattern of cultivated behavior. ${ }^{26}$

A room intended for formal banquet performance arranged in the Roman style was called triclinium. The rabbis borrowed the term but it is a common assumption that the rabbis used the loanword טריקלין, to refer to any kind of dining hall. ${ }^{27}$ According to Klein, the loanword "primarily reflects the arrangement of furniture, which would be set up in rooms of varying statures, scales and shapes, and consequently endows them with this name."28 In the Roman tradition the design of the mosaic floors of dining rooms in the

\footnotetext{
23 Dunbabin, The Roman Banquet, 37; Klein, "Torah in Triclinia," 331.

24 Dunbabin, The Roman Banquet, 38.

25 Smith, From Symposium to Eucharist, 26.

26 Dunbabin, The Roman Banquet, 11.

27 Klein, "Torah in Triclinia," 342.

28 Klein, "Torah in Triclinia," 343.
} 
Roman style marked the area along the walls where the wide couches were to be arranged in the typical $p i$ shape of the Roman triclinium or three-couch room positioned at right angles to one another. ${ }^{29}$ The link between reclining and hierarchy was manifested in the designation of the three couches. ${ }^{30}$ "The couch on the right was designated lectus summus, meaning high position; the middle couch was called medius or middle position; and the couch on the left was locus imus, or the lowest position."31 "The participants in the convivium reclined diagonally, three per couch, with their heads to the center of the room." 32

As already mentioned above, each of the sixteen rectangles created by the six main arteries that run through the city in the text of New Jerusalem (fig. 1) is divided by a number of streets creating square insulae (fig. 2). Each insula has four gates and consists of sixty identical units all equipped with the same number of couches (4Q554 1 ii 11-15; 1 iii 13-22; 4Q554a 1 3-13; 5Q15 1 ii 1-16; fig. 3). According to Milik the ground floor of these units is called בתי מכלא, "dining rooms", according to Puech they are called בתי מזגא, "banquet houses/rooms"33 (5Q15 1 ii 10//4Q554a 17 ), literally "the houses of the mixed wine." ${ }^{34}$ The term as such seems directly related to the mixing of wine, an important feature of a formal banquet. ${ }^{35}$ The rectangular ground plan of each banquet room measures nineteen by twelve cubits (4Q554a $17 / / 5 Q_{15} 1$ ii 10-11). Each of the sixty banquet rooms of an insula had twenty-two couches and eleven windows above the couches (5Q15 1 ii 11//4Q554a 1 7-8). In addition, the specific term "couches" (ערשין) refers to pieces of furniture meant for reclining in the context of a banquet as the banquet rooms are called בתי מזגא. In addition, the specific term "couches" (ערשין) very probably refers to pieces of furniture meant for reclining in the context of a banquet. Identification of the couches mentioned in New Jerusalem with the Greek klinai is possible because of a bilingual

29 Dunbabin, The Roman Banquet, 38, 42; Klein, "Torah in Triclinia," 332; Smith, From Symposium to Eucharist, 17.

30 Dunbabin, The Roman Banquet, 39, 43 (with figure 21); Klein, "Torah in Triclinia," 332.

31 Smith, From Symposium to Eucharist, 17.

32 Klein, "Torah in Triclinia," 332.

33 5Q15 1 ii 10//4Q554a 17; Milik, DJD 3:19o: "salles à manger"; Puech, DJD 37:94: "salles à manger ou de banquet," 143: "maisons de banquet," and 145: "les maisons/salles de banquet." The reading by Puech is hardly supported by the remnants of the signs on the photographs (cf. Levy Digital Library 41.032).

34 Cf. Tg. Prov. 23:30: "Those who delay over wine and go and seek out 'the wine-house' (מית). מזגא)." See John F. Healey, "The Targum of Proverbs," in The Aramaic Bible (Edinburgh: T\&T Clark, 1991), i-viii and 1-65 (50); Marcus Jastrow, A Dictionary of the Targumim, The Talmud Babli and Yerushalmi, and the Midrashic Litarature (Peabody, MA: Hendrickson Publishers, 2005): בית מזגא, "drinking house."

Smith, From Symposium to Eucharist, 30. 
inscription (CIS II 3912) from the temple of Baal Shamin in Palmyra in which the emperor Trajanus Hadrianus (117-138 CE) is mentioned. The main text in Greek has klinēn where the Middle Aramaic text has ערשן in the context of a banquet (כפתא).36 According to Dirven, the word כפתא is hardly ever used for a banqueting room, but in Hatra and in the aforementioned bilingual inscription from Palmyra the term is used in this sense. The word גנא, "to recline, to lie down," leaves no doubt as to the function of this כפתא in Temple XIII in Hatra. ${ }^{37}$ I accept that כפתא in the Palmyrene text has the same meaning as in Hatra and consequently refers to a banquet context.

Each banquet room in New Jerusalem has twenty-two couches and eleven windows as previously mentioned. According to Graham, at least in Olynthos "the andron was placed next to the street in order to receive light from the windows." 38 This observation is confirmed by Hoepfner who mentions windows of andrones facing the street. ${ }^{39}$ Hellmann confirms the possibility of andrōnes with windows. ${ }^{40}$ Excavations in the Karian Sanctuary of Zeus Labraundos in Labraunda (Asia Minor; fourth century $\mathrm{BCE}^{41}$ ) revealed the presence of two andrōnes, Andrōn A, ${ }^{42}$ the andrōn of Idrieus, and Andrōn B, ${ }^{43}$ the andrōn of Maussollos. In Andrōn A ten large windows have been preserved, three in each long side of the banquet room. In both andrōnes was room for about twenty couches. The explicitly mentioned presence of windows in banquet rooms in New Jerusalem is not surprising. Interesting is the implicit suggestion that there is a relationship between the number of couches and the number of windows. The text of New Jerusalem does not enable one to establish the connection between the couches and the windows. Furthermore, the text as preserved does not enable one to determine the arrangement of the couches. Arrangement in the Greek way seems more probable because of the number of twenty-two couches. The Roman triclinium consists of three couches, each occupied by three participants.

36 Delbert R. Hillers and Eleonora Cussini, Palmyrene Aramaic Texts (Baltimore, MD: Johns Hopkins University Press, 1996), 56-57.

Lucinda Dirven, "Palmyrenes in Hatra: Evidence for Cultural Relations in the Fertile Crescent," Studia Palmyreńskie 12 (2013): 49-6o (54, note 24).

38 J. W. Graham, “Olynthiaka," Hesperia 22 (1953): 196-207 (203).

39 Wolfram Hoepfner et al., "Die Epoche der Griechen," in Geschichte des Wohnens, ed. Wolfram Hoepfner (Stuttgart: Deutsche Verlags-Anstalt, 1999), 1:273, 418.

$40 \quad$ Hellmann, L'architecture grecque, 50.

41 Pontus Hellström, Labraunda: A Guide to the Karian Sanctuary of Zeus Labraundos (Istanbul: Ege Yayınları, 2007), 19.

42 Hellström, Labraunda, 126-33.

43 Hellström, Labraunda, 84-91. 


\subsection{Architectural Typology and Use}

An important lead that enables one to identify the character of the city described in New Jerusalem is offered by comparison of the architectural typology of the "Largest Peristylium" in Alexandria with that of an insula as described in the Aramaic text. In Ancient Greece dining rooms could be part of private dwellings or of buildings with a public character such as the South Agora and the Pompeion in Athens ${ }^{44}$ or the palace of Philippos II in Aigai (fourth century BCE) ${ }^{45}$ Dining rooms could be arranged in clusters of small groups as evidenced by the Asklepieion at Corinth. ${ }^{46} \mathrm{~A}$ specific kind of organization of space and form is offered by a building complex in Alexandria which Hoepfner assumes to be the "Largest Peristylium" as mentioned by Polybius in his Histories. ${ }^{47}$ The building complex is surrounded by the streets R1, R2, L3, and $\mathrm{L}_{4}$ and probably dates from the first decades of the third century вСЕ. ${ }^{48}$ According to Hoepfner, the "Largest Peristylium" is part of a large andrōn, "eines großen Bankethauses." 49 The remains of two mosaic floors and one capital of an early Corinthian pilaster on the west side of the building complex point in the direction of dining rooms and couches, i. e. a banquet culture. According to Hoepfner, the discovery of a mosaic floor on the western side of the "Largest Peristylium" and adjacent archeological remains point in the direction of a rectangular compound which at least at its eastern side also consisted of dining rooms. ${ }^{50}$ The remains of another mosaic floor in the centre of the building complex also belonged to a banquet room..$^{51}$

Thanks to overlapping fragments of three manuscripts of New Jerusalem (4Q544, 4Q554a, and 5Q15) the description of a specific type of compound, which covered the largest part of the city, has been preserved in a surprisingly complete state. The manuscripts describe square compounds, consisting of four gates and sixty identical units as already mentioned above. The author of

44 Pantel, La cité au banquet, 553, 555.

45 Hoepfner et al., "Die Epoche der Griechen," 327-29.

46 Jürgen Riethmüller, Asklepios: Heiligtümer und Kulte (Heidelberg: Verlag der Archäologie und Geschichte, 2005), 1:253 (with figure 36).

47 Polybius, The Histories, 15.25.3 (cf. Hoepfner et al., "Die Epoche der Griechen," 464): megiston peristylon. See also Judith McKenzie, The Architecture of Alexandria and Egypt c. 300 BC to $A D 170$ (New Haven, CT: Yale University Press, 2007), 67.

48 Hoepfner et al., "Die Epoche der Griechen," 464-66: "Grösstes Peristyl." See fig. 4-5.

49 For a discussion of the nature of the "Largest Peristylium" see Hoepfner et al., "Die Epoche der Griechen," 464-66.

5o Hoepfner et al., "Die Epoche der Griechen," 465; Judith McKenzie, The Architecture of Alexandria and Egypt c. 300 BC to AD 170, 66, 68.

$5^{1}$ Hoepfner et al., "Die Epoche der Griechen," 466. 


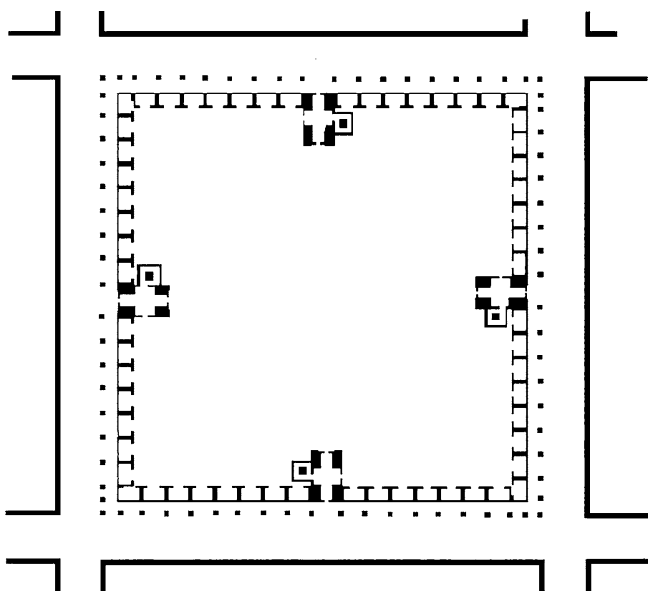

FIGURE 3

Ground plan of an insula in New Jerusalem

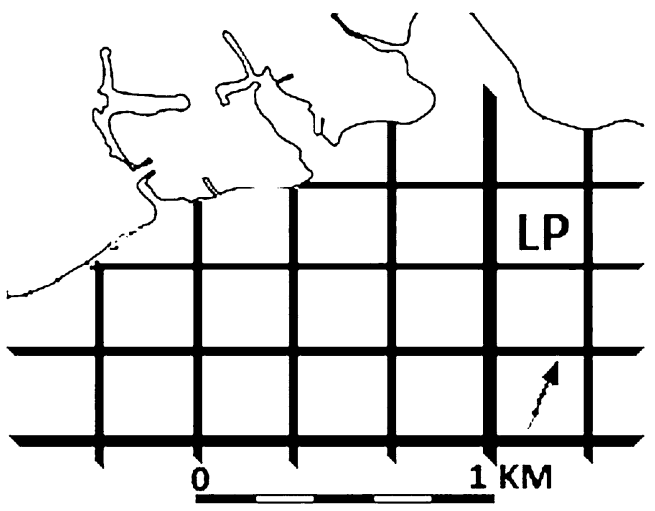

FIGURE 4

Location of the "Largest Peristylium" (LP) on a schematical city plan of Alexandria

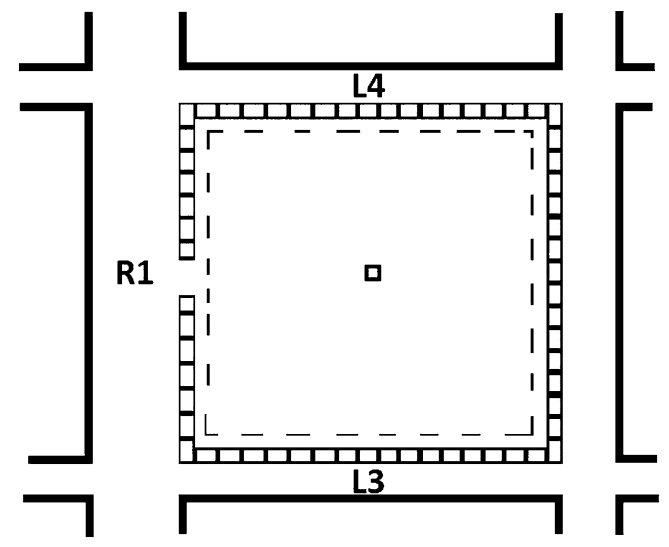

FIGURE 5

Conceptual representation of the ground plan of the "Largest Peristylium" 


\begin{tabular}{|c|c|c|}
\hline & $\begin{array}{l}\text { Insula in Aramaic } \\
\text { New Jerusalem (fig. 3) }\end{array}$ & $\begin{array}{l}\text { "Largest Peristylium" in } \\
\text { Alexandria (fig. 5) }\end{array}$ \\
\hline $\begin{array}{l}\text { 1. Shape of the ground } \\
\text { plan }\end{array}$ & Square & rectangular, almost square \\
\hline 2. Surroundings & \multicolumn{2}{|c|}{ streets on all four sides } \\
\hline 3. Components & \multicolumn{2}{|c|}{$\begin{array}{l}\text { (mostly) identical rectangular units built along the } \\
\text { four sides }\end{array}$} \\
\hline 4. Peristyle & $\begin{array}{l}\text { surrounded either by a } \\
\text { peristyle or a side-walk on } \\
\text { the outside }\end{array}$ & $\begin{array}{l}\text { it has a peristyle and a } \\
\text { garden on the inside }\end{array}$ \\
\hline 5. Wide inner space & no further specification & a smaller building \\
\hline $\begin{array}{l}\text { 6. Entrance of the } \\
\text { compound }\end{array}$ & four gate buildings & at least one gate \\
\hline 7. Entrance of the units & $\begin{array}{l}\text { each unit has its entrance on } \\
\text { the inside of the compound }\end{array}$ & $\begin{array}{l}\text { almost each unit has its } \\
\text { entrance on the inside of } \\
\text { the compound }\end{array}$ \\
\hline
\end{tabular}

New Jerusalem refers to the use of the modules by the term בתי מזגא, "banquet rooms," which was already dealt with above.

The typological comparison of the ground plan of an insula and the ground plan of the "Largest Peristylium" from seven viewpoints in the table below enables one to conclude that the two types of compound are very similar from the typological point of view, including the specific use of them. Both compounds belong to the same basic type of architecture in which a space is enclosed by four planes, while around it, identical spaces of the building are organized. ${ }^{2}$

Moreover, the "Largest Peristylium" and the insula as described in New Jerusalem are similar in use. Both building complexes are intended for banquet performance on a broad scale. The archeological remains of the "Largest Persitylium"-mosaic floors and their surroundings—clearly point in the direction of banquet rooms in the Greek tradition with couches along the walls of the andrōn. The Aramaic text refers to couches, intended for reclining, and banquet rooms, called "rooms of mixing wine," as discussed above.

$5^{2}$ Francis D. K. Ching, Architecture: Form, Space, and Order (Hoboken, NJ: John Wiley and Sons, 2007), 156. 


\section{Eating and Drinking and the Sacred Character of Formal Banquets}

As already mentioned in the introduction above, according to the Greek tradition a formal banquet had two well defined courses. First, the meal of the evening was eaten during the deipnon. Second, the symposion or drinking party was performed, during which the entertainment was presented. ${ }^{53}$ The Roman formal meals had the same two basic courses but the Romans added appetizers, called propoma, at the beginning of the meal. ${ }^{54}$

Because of the nature of the second course wine was obviously an important component of a Greco-Roman banquet. It was always drunk mixed, which means blended with water. ${ }^{55}$ The presence of the krater stresses one of the main aspects of the classical Greek symposion, viz. the communal distribution and consumption of wine by the participants..$^{56}$ In the Hellenistic period, the krater disappears from the repertory of ceramics. Probably the practice of communal mixing of wine may already have been in decline. At least the wealthy members of society may have preferred to have their wine served in small jugs, mixed in the cup to their own taste. ${ }^{57}$

In New Jerusalem, wine is not mentioned in the context of banquet practices but probably in connection with cereal and libation offerings that accompany offerings by fire because of the mention of "oil and wine," "a pleasant aroma," and "the altar" (cf. Num 15:3-4): "[...] in front of [the] al[tar] ... with [...] before it [...]oil and wi[ne ...]for him/it[...] a pleas[ant aro]ma[...]" (11Q18 29 1-6). This fragment is most likely to be connected with the temple cult rather than with banquet practices.

A tiny fragment of New Jerusalem mentions eating and drinking as well as sacrifices. The fragmentary condition of the text does not allow one to connect "the sacrifices of Israel" with "and they will/shall eat and $\mathrm{dr}[\mathrm{ink}$...]" in a substantiated way. Neither does it establish the form of worshipping, viz. temple cult or banquets, "[...] from the sacrifices of Israel [...] ... and in the night [...] the $\ldots$ and the glory $[\ldots] \ldots$ its flesh, which $[\ldots] \ldots$ with it, and from $[\ldots] \ldots$ and they will/shall eat and dr[ink ...]" (11Q18 25 1-6).

All formal Greek banquets always have sacred components. Meat and wine, which together with bread are the central types of food/drink at a banquet, are

53 Smith, From Symposium to Eucharist, 27; see also Pantel, La cité au banquet, 4, 483.

54 Smith, From Symposium to Eucharist, 27.

55 Dunbabin, The Roman Banquet, 20; Shimoff, "Banquets: The Limits of Hellenization," 442; Smith, From Symposium to Eucharist, 32.

56 Dunbabin, The Roman Banquet, 20.

57 Dunbabin, The Roman Banquet, 24. 
always related to deities. ${ }^{58}$ The meat always comes from ritually slaughtered animals and the wine is directly related to Dionysos. During an ordinary formal meal it was customary to offer libations or prayers to the gods no matter how "secular" the overall context was. ${ }^{59}$ When unmixed wine was served, it was customary to greet it with the words "to the good deity!"60 According to the same custom, one would cry out "to Zeus Savior!" when the first cup of mixed wine was passed around after the meal. The reference to the "good deity" was generally understood as a reference to Dionysos. According to another custom, ${ }^{61}$ three different bowls were mixed: the first cup was dedicated to the Olympian gods, the second to the heroes, and the third to Zeus Savior. Each time the wine was ladled into the cup, the name of the deity was pronounced over it: "to the good deity!" or "to Zeus Savior!" The host or symposiarch then pronounced the name of the deity again and poured out a portion into the fire on the floor. He took a sip and passed the cup around for each guest to sip, saying the name of the deity. A minor component of the formal banquet culture is the transition from the eating part to the drinking part of the meal. Even this minor component shows that in the Greco-Roman tradition no formal banquet is ever purely secular in nature: To mark the transition from the main course to the second course, in addition to rearranging the furniture and cleaning up the room, "a libation of unmixed wine was offered 'to the good daemon' or 'good deity' (agathou daimonos) and a 'paean' was sung (paianizein)." ${ }^{2}$ On this occasion the paean was probably a solemn song or chant with religious significance. ${ }^{63}$

Water was not only used in order to mix wine but also to wash the hands of the participants and to clean up the dining room. Water was poured over the participants' hands twice, first in order to signal the beginning of the meal and a second time during the transition from the first course of the meal to the second. ${ }^{64}$ As mentioned in the previous section, the transition from the first course of the banquet to the second was marked by an elaborate formal ritual.

\footnotetext{
$5^{8}$ Smith, From Symposium to Eucharist, 31-33.

59 Smith, From Symposium to Eucharist, 6.

6o Smith, From Symposium to Eucharist, 29.

61 Smith, From Symposium to Eucharist, 29-30.

62 Smith, From Symposium to Eucharist, 28.

63 Smith, From Symposium to Eucharist, 30.

64 Shimoff, "Banquets: The Limits of Hellenization," 441-42.
} 
In the cleaning up of the floor with water during the transition from the deipnon to the symposion proper and also afterwards when the banquet room was cleaned up once the symposion was over, undoubtedly the drainage of water was involved. ${ }^{65}$ This might explain the mention of an outer gutter in the description of the modules in New Jerusalem: "And on their (= the banquet rooms') side was the outer gutter (אמה בריתא)" (4Q554a 1 8//5Q15 1 ii 12). In the standard description by Roux ${ }^{66}$ of banquet houses referred to by Pantel, drainage of the water used in order to clean up the room is performed by a drain at ground level, ${ }^{67}$ under the threshold, or in the wall. ${ }^{68}$ This is also the reason why the couches were arranged along the walls on a continuous masonry ledge not only in order to keep them from being hit by the broom sticks but also to protect them against the water. ${ }^{69}$

\section{"Rooms of Joy" in New Jerusalem and "Festive Joy" in Other Early Jewish Texts}

\subsection{Introduction}

In order to support the view that in the city described in New Jerusalem the cult is not only performed by the traditional Jewish form of worshipping in the temple complex but also by a pious and respectful banquet culture, I shall focus on two aspects of the Greco-Roman banquet: entertainment in the form of "table talk" and "festive joy."

Entertainment was an important component of the banquet in GrecoRoman style..$^{70}$ The participants in a banquet could amuse one another by party games such as posing riddles, by playing kottabos, a drinking game where the last drops in the wine cup would be flung at a target in the middle of the room, and by engaging in sex. The participants could also be entertained by dancers and musicians or by a kind of dramatic performance. Last but not least, the participants could engage in conversations or philosophical discussions.

\footnotetext{
65 Pantel, La cité au banquet, 307.

66 Georges Roux, "Salles de banquets à Délos," in Études Déliennes, BCHSuppl. 1 (Paris, 1973), $525^{-54}\left(55^{2}\right)$.

67 Hellmann, L'architecture grecque, 50 .

68 Pantel, La cité au banquet, 305.

69 Hellmann, L'architecture grecque, 50; Pantel, La cité au banquet, 305.

70 Shimoff, "Banquets: The Limits of Hellenization," 442, 446; Dunbabin, The Roman Banquet, 19-20; Smith, From Symposium to Eucharist, 34-38.
} 
The ancient Greeks had a large number of terms to refer to banquets. ${ }^{71}$ Two of them clearly have a festive connotation: euphrosyne $\bar{e}^{72}$ "festive joy," and euōchia, "feast."73 The term "festive joy" does not refer to an individual experience but to a social experience based on the form and function of the banquet, of which it is an inherent part. ${ }^{74} \mathrm{~A}$ basic social function of the meal, that of giving pleasure, ${ }^{75}$ has been idealized and made into a principle which defines the proper meal. ${ }^{76}$ "Festive joy" was a rule according to which a "proper" banquet was judged. ${ }^{77}$ In connection with wine it was considered to be a gift of the gods. ${ }^{78}$ Yet, in the philosophical tradition the term "festive joy" transcends the purely secular and mundane interpretation of banquet conviviality and gives a more profound signification to the convivial experience. This interpretation of "festive joy" corresponds to a great extent to the use of pleasure in philosophical discussions of meal ethics. ${ }^{79}$

In order to enable one to accept that worship in the city described in New Jerusalem could take the form of banquet performance, the Epicurean view on the formal banquet is interesting because of the distinction it makes between two complementary kinds of pleasure. A closer look at the philosophical banquet enables one to take the concepts pleasure and festive joy into consideration from a more respectful point of view than that of a banquet culture dominated by immoderate physical pleasure. The ideal Epicurean banquet presupposes a microcosmos in which one is able to experience the acceptable feelings of static and active pleasure. Making a distinction between static and active pleasure, two basic concepts of his philosophical system, enables Epicurus to transcend the focus on physical pleasure. ${ }^{80}$ Static pleasure on the one hand not only applies to the body, which means freedom from pain, but also to the mind, which means peace of mind. Active pleasure on the other hand consists of joy and delight or "festive joy." In the microcosmos of the banquet one experiences the satisfaction of basic needs, viz. static pleasure, which refers to a state of rest. The latter kind of "joy" applies both to the body, "freedom from pain," and to the mind, "peace of mind". Active pleasure applies

71 Pantel, La cité au banquet, 261-89.

72 Pantel, La cité au banquet, 273-75. Smith, From Symposium to Eucharist, 80.

73 Pantel, La cité au banquet, 275-76 ("festin").

74 Smith, From Symposium to Eucharist, 81.

75 Smith, From Symposium to Eucharist, 10.

76 Smith, From Symposium to Eucharist, 12.

77 Smith, From Symposium to Eucharist, 80.

78 Smith, From Symposium to Eucharist, 12, 80.

79 Smith, From Symposium to Eucharist, 37-38, 64.

8o Smith, From Symposium to Eucharist, 10, 59-6o. 
to "joy", chara, and "delight" or "festive joy", euphrosyne, both terms referring specifically to a more elevated state of mind. According to Smith, "the concept of pleasure as the highest good was not to be defined as 'unbroken succession of drinking-boors and of revelry' but as 'sober reasoning. " 81

\subsection{Ben Sira and the Letter of Aristeas}

Ben Sira (ca. $190 \mathrm{BCE}$ ) is represented as the testimony of a scholar in the Jewish wisdom tradition who is engaged in training young men in the rules of ethical living. The testimony is embedded in Jewish tradition because it explicitly respects the Torah, viz. "the law of the Most High." ${ }^{82}$ A considerable part of the instruction in Ben Sira concerns meal etiquette in the context of a banquet culture. The author does not deal systematically with a formal banquet but gives advisory instructions scattered all over the text. ${ }^{83}$ Despite this inconvenience, Smith succeeded in drawing up a picture of the formal banquet that the author of Ben Sira probably had in mind. According to Smith, this picture shows a remarkable similarity to the formal Greek banquet tradition. He recognizes the following features: the importance of the invitation, the luxurious setting, the ranking of the guests, the role of the symposiarch, the posture at the meal, and entertainment in the form of music and "table talk." When music was not present, conversation could serve as an alternative form of entertainment. Whenever conversation does take place it has to be wise. This means it has to be concerned with the law, viz. "the law of the Most High." 84

Meal sayings in Ben Sira (31:12-32:13) are very similar to material in the banquet tradition of Greek literature and show similarity with the Greek philosophical tradition insofar as the author sees the banquet as a place of instruction. ${ }^{85}$ His preference for moderate banquets and his rejection of the immoderate versions fit well in the Epicurean view discussed above, as can be inferred from the view on the use of wine. On the one hand, moderation in drinking is recommended. Wine is considered to be life to men if it is drunk in moderation. Wine has been created to make men glad. When drunk in season and temperately, wine is rejoicing of heart and gladness of soul. Drunk to excess, wine is bitterness of soul, with provocation and stumbling (31:27-29). On the other hand, wisdom and conversation are preferred to wine and music (40:20-21).

\footnotetext{
81 Smith, From Symposium to Eucharist, 59.

82 Smith, From Symposium to Eucharist, 139.

$83 \quad 6: 10-12$; 9:15-16; 11:29, 34; 12:12; 13:8-13, 17-18; 18:32-33; 19:1-3; 23:6; 29:21-28; 31:12-31; 32:113; 33:4-6; 34:9-12; 36:21-26; 37:1-37; 38:1-34; 39:1-11; 40:20-21, 29; 41:19.

84 Smith, From Symposium to Eucharist, 139.

85 Smith, From Symposium to Eucharist, 142-44.
} 
According to the Letter of Aristeas (са. 170 BCE), the chief librarian of the king of Egypt urges the latter to have the Jewish law translated into Greek in order to add the knowledge of the Jews to the vast collection of books the empire had already collected. The high priest Eleazar chooses six men from each of the twelve tribes. On their arrival in Egypt the 72 translators are invited to a banquet, the course of which is reported extensively (185-294). The banquet is explicitly referred to as a symposion $(181,186,203,220,236,286,294)$.

As already mentioned above, in the Greco-Roman banquet tradition each position on the couches was ranked. The guests were placed on the couches according to their social rank. At private Greco-Roman banquets the host designated the positions that the guests would occupy. The participants in the banquet of the Egyptian king recline (182), arranged according to seniority (187). As a decent host the king seriously takes into account the customs of his Jewish guests. The preparations for the banquet are made in accordance with the customs of the Jewish participants, "in order that there might be no discomfort to mar their enjoyment" (182).$^{86}$ The king dispenses with the services of the sacred heralds and the sacrificing priests and the others who are accustomed to offer the prayers, and calls upon Eleazar, the oldest of the Jewish priests, to offer prayer instead (184-185). The king takes up the function of symposiarch in drinking to the health of the participants $(235,261,264,274$, 293) and in respecting a strict order during the round of questions, which he leads with a strong hand (e.g. 187 and 189). In the Greco-Roman banquet tradition each banquet performance has a presiding officer or "symposiarch." ${ }^{87} \mathrm{He}$ sets the rules for the drinking party. His first duty is to decide the proportions of the mixture of water to wine. He decides the size of the portions of wine to be served to the guests.

"Festive joy" is an important feature of the banquet in which the Jewish translators participate and directly connected with the contents of the "table talk" as can can be inferred from the following quote: "At these words there was a burst of applause with shouting and jubilation lasting for some while; and thereafter they betook themselves to the enjoyment of the banquet, which had been prepared" (186).

Applause (186, 200, 200, 230, 247, 273, 277, 292), shouting (186, 261, 292, 294), and jubilation $(186,292)$ are signs of approval $(247,292,294)$ that qualify the "festive joy" as the general atmosphere of the banquet. "Festive joy" itself is referred to explicitly at many occasions either in its individual capacity, viz.

86 Quotations from the Letter of Aristeas are taken from Henry St. John Thackeray, The Letter of Aristeas (London: SPCK, 1917).

87 Smith, From Symposium to Eucharist, 33-34. 
experienced by the king $(198,207,232,235,253,268,288,294)$, or its collective capacity, viz. experienced by the translators $(182,186,202,247,261,273$, 274, 294).

"Table talk" on a high moral and intellectual level is praised as the most elevated form of entertainment by comparing it to harmonious and sweet music. In answer to the question of the king, "what should be one's conduct at banquets?" (286), the participant says, "you should invite such as are lovers of learning and able to suggest what may be useful to the kingdom and to the lives of your subjects. No more harmonious or sweeter music could you find. For these are beloved of God, since they have trained their minds in the highest learning" (286-287). The main part of the report of the course of the banquet is dedicated to the entertainment in the form of high level "table talk." In order to profit from the wise teachings of his guests on the art of ruling, the king puts the wisdom of each participant in the banquet to the test, asking philosophical questions with a strong moral slant. In their answers, the Jewish translators always refer to the authority of the Most High.

\subsection{Texts from the Caves of Qumran}

Eating and drinking on a massive scale being compatible with a formal sacred context is shown in the Temple Scroll (second half of the second century BCE), on the occasion of two festivals of the first fruits. On the Festival of the First Fruits of the Wheat hierarchical order is respected. ${ }^{88}$ First the priests shall eat the first fruits in the inner courtyard of the Temple. Afterwards all the people shall eat new bread made of fresh ripe ears (11QT $\left.{ }^{\mathrm{a}} 19: 5^{-7} / / 11 \mathrm{QT}^{\mathrm{b}} 3: 23-24\right)$. If one assumes that the sequential order of the text reflects a chronological order one can presume that - after the offerings have been eaten in the outer courtyard $\left(11 \mathrm{QT}^{\mathrm{a}} 21: 3 / / 11 \mathrm{QT}^{\mathrm{b}} 5: 7\right)$-all the people, from the oldest to the youngest, shall drink new wine and rejoice, after the priests, the Levites, and the chiefs of the standards have done so (11QT $\left.{ }^{\mathrm{a}} 21: 4-10 ; 11 \mathrm{QT}^{\mathrm{b}} 5: 8-13\right)$. As Schiffman notes, "in Second Temple times, festive shelamim sacrifices were offered as part of the celebration of the pilgrimage festivals and these offerings were consumed by the participants." 89

Apart from references in the Temple Scroll to sacrificial meals eaten within the walls of the temple two other texts explicitly refer to formal meals, viz. the

88 Johann Maier, Die Tempelrolle vom Toten Meer und das “Neue Jerusalem," чтв 829 (München: Ernst Reinhardt Verlag, 1997), 107.

89 Lawrence H. Schiffman, "Shelamim Sacrifices in the Temple Scroll," ErIsr 20 (1989): 176*$83^{*}\left(179^{*}\right)$. 
Rule of the Community (1QS 6:4-5, 20-21), ${ }^{90}$ and the Rule of the Congregation (1QSa $2: 17-22) .{ }^{91}$ In both texts the meals concerned are also related to the first fruits.

The Rule of the Community (end of second century BCE) stipulates that where there are ten men of the Community council there has to be a priest among them. Every one shall sit before him by rank. In this way every one shall be asked for his opinion on any matter. When they prepare the table to dine or the new wine for drinking, the priest shall bless the first fruits of the bread or the new wine. In any place where the Ten assemble, there shall be a man to interpret the law day and night, always, one man relieving another. The Many shall be on watch "together for the first third of every night of the year, reading aloud from the book, interpreting Scripture, and praying together" (1QS 6:4-8). ${ }^{92}$ The text reflects a number of features of a Greco-Roman banquet: the sacred nature of the meal because of the mandatory presence of a priest, the importance of the ranking of the participants, the blessing of the wine, and conversation on serious matters as in Greco-Roman philosophical banquets. Although the direct connection with the preceding regulations concerning the meal is not clear, the text nevertheless also emphasizes the reading of holy scriptures and the study of the regulations as well as the importance of blessing.

The Rule of the Congregation (second half of the second century вСE) refers to a sacred meal within an eschatological context as evidenced by the mention of the "last days" (1QSa 1:1) and the presence of the Messiah (1QSa 2:11-12). The participants in the meal, the priest, as head of the entire congregation of Israel, the sons of Aaron, the priests appointed to the banquet of the men of reputation, the heads of the thousands of Israel, the heads of the congregation's clans, and the wise men of the holy congregation, are not reclining but sitting (ישב, 1QSa 2:13, 14) in a hierarchical order. The communal table is set to drink wine. When the wine is poured for drinking, the priest shall bless the first portion of the bread and next the wine. The Messiah also blesses first the bread. These stipulations have to be observed at each meal when at least ten men of the community are gathered (1QSa 2:11-22).

$90 \quad$ M. Delcor, "Repas cultuels esséniens et thérapeutes, thiases et haburoth," $\operatorname{RevQ} 23$ (1968): 401-25 (412-15); Edouard Lipiński, "Le repas sacré à Qumrân et à Palmyre," ErIsr 20 (1989): $130^{*}-34^{*}\left(130^{*}-31^{*}\right)$; Smith, From Symposium to Eucharist, $155^{-56}$.

91 Delcor, "Repas cultuels esséniens et thérapeutes, thiases et ḥaburoth," 412-15; Lipiński, "Le repas sacré à Qumrân et à Palmyre," 130-31; Smith, From Symposium to Eucharist, 156-57.

92 Donald W.Parry and Emanuel Tov, eds., The Dead Sea Scrolls Reader. Second Edition, Revised and Expanded. Vol. 1 (Leiden: Brill, 2014), 16-17. 


\subsection{The Banquet in the Rabbinic Literature}

The banquet modus operandi as such was adapted by the early rabbis in their specific way. ${ }^{93}$ The rabbis and sages indicated clearly that some Hellenistic practices were absolutely unacceptable. The rabbinic literature sanctioned Hellenistic banquets as long as the worst excesses-from the point of view of the rabbis—-were expurged. ${ }^{94}$ They considered the libations to gods during Greco-Roman banquets flagrantly idolatrous. Once the idolatry and licentiousness were eliminated and a few Jewish practices were added, the Greco-Roman banquet seemed more acceptable to them. ${ }^{95}$ The rabbis "required a distinctly Jewish ambiance, fostered by discussion of Scripture, sacred songs, and especially the presence of students of Torah. The table itself was sanctified and characterized by the rabbis as a substitute for the holy altar in the Temple; such statements must have encouraged even pious Jews to adopt some features of the Greco-Roman banquet."96

The data from the Tannaitic literature are important in order to recognize a continuous influence of the Greco-Roman banquet tradition. The texts date from the third to the seventh century CE. It may be assumed that they contain traditions that date from as early as the first century CE. According to Smith, it is possible to perceive the basic features of a Greco-Roman banquet in the Tannaitic texts. ${ }^{97}$ Smith refers to the Tosefta as describing a meal that consists of three courses: appetizer, main course, and dessert. Hands are washed twice. The guests move from the vestibule to the dining room and there is a change of posture, i.e. from sitting to reclining. Mixed wine is served during the meal and wine is served at the end of the meal. In the anteroom every participant says the benediction over the wine for himself; in the dining room benediction is said on behalf of all: "Blessed art Thou, O Lord, our God, King of the universe, Creator of the fruit of the vine." ${ }^{\prime 98}$ In the Tosefta, the order of reclining is discussed (t. Ber. 5:5). Distinction is made between a biclinium, the setting of two adjacent or parallel reclining couches, and a triclinium, the typical Roman $p i$-shaped setting for reclining. The rabbinic use of "upper," "middle," and "lower" couches, as well as the reference to reclining "above" and "below," follows the Latin terminology: summus, medius, and imus, and supra and infra. ${ }^{99}$

\footnotetext{
93 Klein, "Torah in Triclinia," 334-41; Shimoff, "Banquets: The Limits of Hellenization," 441, 444-47; Smith, From Symposium to Eucharist, 144-50.

94 Shimoff, "Banquets: The Limits of Hellenization," 447.

95 Shimoff, "Banquets: The Limits of Hellenization," 444.

96 Shimoff, "Banquets: The Limits of Hellenization," 444-45.

97 Smith, From Symposium to Eucharist, 145.

98 Smith, From Symposium to Eucharist, 146.

99 Klein, "Torah in Triclinia," 335.
} 
The rabbinic response to the Hellenistic challenge of banquets did not only consist in a lukewarm, resigned acceptance of inevitable social pressures. ${ }^{100}$ The rabbis did not only accept the Hellenistic banquet but also integrated it in the cult. The Passover meal, one of the major festivals in the Jewish year, was primarily a sacrificial meal prior to the destruction of the temple in $70 \mathrm{CE}$. It required a pilgrimage to Jerusalem, where the sacrifice was held. The Passover sacrificial ritual differed from other sacrifices in that the layperson performed his own sacrifice, although presumably the priest would have to officiate in parts of it, especially in the ritual activities concerning the sacred blood of the animal. The description of a Passover meal is elaborately described in the Mishnah (m. Pesah. 10:1-9), with the specification that the diners recline, the division of the meal into two (or three) courses, and the benediction of the wine that begins the formal banquet proper. Four cups of wine are mentioned (m. Pesah 10:1, 7). The second and the third cup are mentioned after the main course, which means during the entertainment or "table talk." As such they are part of the symposion following the meal proper. ${ }^{101}$ The table is interesting if one intends to read New Jerusalem from the vantage point of the banquet culture. From a general point of view the "table talk" fits into the pattern of the Greco-Roman banquet. From the specific Jewish point of view it shows how the Greco-Roman banquet culture had been adapted to the specific Jewish needs. The posture at the meal is reclining (m. Pesah. 10:1). The use of the question-and-answer format (m. Pesah. 10:4), the motif of instruction, the father instructing his son (m. Pesah. 10:4), and the motif of composing etymological word games on the food, in this case the comparison of eating bitter herbs to the experience of the ancestors whose lives were embittered by the Egyptians in Egypt (m. Pesah. 10:5), are part of the Greco-Roman banquet tradition. ${ }^{102}$ The main part of the "table talk" consists of thanking, praising, and singing the Hallel-psalms ${ }^{103}$ to God who set the Jews free from slavery in Egypt (m. Pesah. 10:5).

\subsection{New Jerusalem}

The text of New Jerusalem contains no reference at all to the sacred nature of the banquets performed in the gigantic city. In the text as preserved no reference is made to the component of the meal that corresponds to entertainment in the form of "table talk" in the Greco-Roman tradition. Neither conversation

\footnotetext{
100 Shimoff, "Banquets: The Limits of Hellenization," 447.

101 Smith, From Symposium to Eucharist, 149-50.

102 Smith, From Symposium to Eucharist, 150.

103 Pss 113-118; cf. b. Pesah. 117a and 118a.
} 
nor reading from Holy Scriptures is mentioned. Singing is also not mentioned. Yet, a tiny fragment of one of the manuscripts of New Jerusalem refers to "rooms of joy": "[...] he said to me: you 〈are $\rangle$ looking at, the one(s)/that, w[ho]/ w[hat] ... in the rooms of joy (בתי חדוא) and to [...]" (11Q18 18 5-6). The reference to "rooms of joy," I suggest, is best understood from the three angles dealt with above: the sacred nature of the banquet, the component of the meal that corresponds to entertainment in the form of "table talk" in the Greco-Roman tradition, and the "festive joy."

Banquet Culture on the City Level

\subsection{Banquet Culture on a Larger Scale}

Ancient Greek temples commonly had dining rooms. ${ }^{104}$ The meals eaten at temple dining rooms were not necessarily sacrificial meals. Some sanctuaries were expected to provide hospitality facilities for pilgrims. The dining rooms tended to have the same structural characteristics as dining rooms in public secular buildings and in private houses. From this one may infer that the meals held in the dining rooms of the temples were not formally different from normal secular meals. The design for temple dining rooms consisted of several small rooms of standard size.

A tiny fragment of the manuscripts of New Jerusalem (11Q18 25 1-6), already referred to above (in section III), mentions eating and drinking as well as sacrifices. However, because of the fragmentary condition of the preserved text it is not possible to infer from it that what was eaten came from sacrifices, in this case from the sacrifices of Israel. Furthermore, it is impossible to identify the location where the eating and drinking were to take place.

\subsection{Banquet Culture on an Even Larger Scale}

Until now it has been established in the present article that the name of the banquet rooms, the arrangement with twenty-two couches and eleven windows, as well as the typological similarity between an insula and the "Largest Peristylium" point to a banquet culture which resembles the Greco-Roman one, at least concerning the aspect of reclining as dealt with above (section II, II). At first sight the performance of a banquet on the city level seems implausible. Yet, Pantel proved the contrary, dealing with a period from the eighth century BCE until the fourth century BCE: Banquets on the city level were announced publicly including the mention of the invited guests. Invited were either all

104 Smith, From Symposium to Eucharist, 73. 
the citizens or all the free inhabitants of a city; sometimes only notables were invited. ${ }^{105}$

How many people could participate in the performance of a massive banquet in the city described in New Jerusalem? The text as preserved does not enable one to calculate this number precisely since, e.g., the inner circumference of the city wall cannot be established because the thickness of the city wall remains unknown. Further, the distance between the insulae facing the city wall and the wall itself on the one hand and the distance between the insulae facing the six boulevards and the edge of these boulevards on the other hand remain unknown. I propose the very conservative estimation of 361,000 couches, which points to 361,000 or 722,000 (two per couch) participants. This number might but does not necessarily explain the high number of 32,900 in 11 Q18 18 1-3: "[...] seven cups and six metal plates, to smell [...]... and above $\langle$ are $\rangle$ seven cauldrons, installed to cook on ston[es ... and al]l of them $\langle$ are $\rangle$ thirty two thousand nine hundred[...]". Because of the eschatological context of the city described in New Jerusalem it does not make sense to give any realistic value to the aforementioned figures.

\section{$7 \quad$ Banquet Culture on the Occasion of Pilgrimage Festivals}

We now turn to the occasion on which the banquet culture on the city level was performed in the gigantic city in New Jerusalem. As mentioned above (section II.I), the ground plan, built up gridwise on different levels, does not seem to point in the direction of a normal residential way of life on a family basis. In phrasing my thesis in the introduction of the present article in terms of two other possibilities, a vast military camp or a pilgrimage city, I only retained the latter because the text of New Jerusalem as preserved contains no indications regarding military confrontation in relation to the function of the walls and gates of the city.

The Torah prescribes that all males must go up to Jerusalem "three times a year" on the three festivals_Passover, Shavuot, and Sukkot (Exod 23:17; 34:23; Deut 16:16; 2 Chr 8:13). ${ }^{106}$ The following quote from the Mishnah-which strengthened my choice of the Greco-Roman banquet culture as a vantage point-implicitly connects the Passover meal with pilgrimage to Jerusalem: "Therefore, may the Lord, our God and the God of our fathers, bring us in peace to the other feasts and pilgrim festivals, which are coming to meet us, while

105 Pantel, La cité au banquet, 380-408.

106 Cf. Moshe David Herr, "Festivals," EncJud 6:765-69 (765). 
we rejoice in the building of our city and are glad in your worship" (m. Pesah. 10:6). ${ }^{107}$ Does the text of New Jerusalem contain indications which point to pilgrimage festivals? Two fragments mention one of these three festivals, viz. Passover: "second blessing [...].. and their celebration offerings and their Passover offerings [...] the [p]riests $\langle$ are $\rangle$ receiving from their hand, that [they have] stretched ou[t]....[and] $\langle$ will $\rangle$ not $\langle$ be $\rangle$ entering in it each pers[on ...] his hands, all ..[...]" (11Q18 16 ii-17 i 1-5), and "[... wh]ole Israel ..[...] vacAT and as soon as ...[...]... the Passover offerings ...[... un]till the sun sets/will set and al $[1 \ldots] \ldots$ their celebration offerings [...]not (?) to satisfy .[...]" (11Q18 27 1-6). Mention of the two other festivals, the Feast of the Harvest (Feast of Weeks) and the Feast of the Tabernacles/Tents/Boots as well as the mention of a commandment of pilgrimage on the three festivals concerned would offer stronger support for the thesis phrased in the introduction of the present article. The text as preserved remains silent in this regard. Two fragments refer to the cult in general without specifying if the cult referred to is the cult in the temple or the performance of a banquet: "[...] offerings of (= intended for) G[od ...]

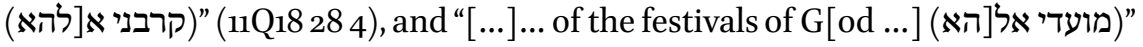
(11Q18 30 4). Anyway, the mention of the Passover festival in the text of New Jerusalem does not rule out the idea of a banquet of pilgrims.

\section{$8 \quad$ Conclusion}

The fragmentary evidence in the manuscripts of the Aramaic text New Jerusalem-although still incomplete-enables one to conclude that in the city described the cult is performed both by the traditional Jewish cult performance in the temple complex and by a respectful and pious banquet custom. Probably after a major reversal in history, a planned city might be intended to accommodate and to enable an enormous amount of people-possibly pilgrims - to perform worship in the form of banquet practices.

It has been possible to produce elements in support of the thesis phrased in the introduction of the present article. Banquet rooms with twenty-two couches and eleven windows clearly point in the direction of reclining and banquet performance. To this one can add the similarity between the "Largest Peristylium" in Alexandria and the insulae in New Jerusalem, from the point of view of architectural typology as well as the use of them for the performance of the banquet practice on a massive scale. The "Largest Peristylium" in Alexandria and the insula in the text of New Jerusalem both contain banquet

107 Cited by Smith, From Symposium to Eucharist, 148. 
rooms. These rooms have a specific design related to the posture at the meal, viz. reclining.

Further, it was possible to fit in a seemingly insignificant element, viz. "the outer gutter," as a logical component of banquet rooms. The frivolously sounding term "rooms of joy" can be understood as referring to pious and respectful "festive joy." If one accepts that the units of the insulae, covering almost the entire city, are intended for banquet performance, then the whole city is intended for such performance except the temple complex. The concept of banquet performance on a city level is well known from Greek and Hellenistic customs. A whole city intended in a uniform and standardized way for banquet performance cannot be intended for a normal residential way of life. One of the remaining possibilities regarding the use of the city is pilgrimage. Because of the mention of one of the three pilgrim feasts, Passover, it is plausible that the city was meant for pilgrims.

\section{Bibliography}

Antonissen, Hugo. "The Visionary Architecture of New Jerusalem in Qumran." Pages 439-8o in Qumran und die Archäologie: Texte und Kontexte. Edited by Jörg Frey, Carsten Claußen, and Nadine Kessler. wUnT 278. Tübingen: Mohr Siebeck, 2011.

Ching, Francis D. K. Architecture: Form, Space, and Order. Hoboken, NJ: John Wiley and Sons, 2007.

Delcor, M. "Repas cultuels esséniens et thérapeutes, thiases et haburoth." RevQ 23 (1968): 401-25.

Dirven, Lucinda. "Palmyrenes in Hatra: Evidence for Cultural Relations in the Fertile Crescent." Studia Palmyreńskie 12 (2013): 49-6o.

Dunbabin, Katherine M. D. The Roman Banquet: Images of Conviviality. Cambridge: Cambridge University Press, 2003.

George, Andrew R. Babylonian Topographical Texts. OLA 40. Leuven: Peeters, 1992.

Graham, J. W. “Olynthiaka." Hesperia 22 (1953): 196-207.

Healey, John F. "The Targum of Proverbs." Pages i-viii and 1-65 in vol. 15 of The Aramaic Bible. Edinburgh: T\&T Clark, 1991.

Hellmann, Marie-Christel. L'architecture grecque: 3. Habitat, urbanisme et fortifications. Paris: Picard, 2010.

Hellström, Pontus, Labraunda: A Guide to the Karian Sanctuary of Zeus Labraundos. Istanbul: Ege Yayınları, 2007.

Herr, Moshe David. "Festivals." EncJud 6:765-69.

Hillers, Delbert R., and Eleonora Cussini. Palmyrene Aramaic Texts. Baltimore, MD: Johns Hopkins University Press, 1996. 
Hoepfner, Wolfram et al. "Die Epoche der Griechen." Pages 123-608 in vol. 1 of Geschichte des Wohnens. Edited by Wolfram Hoepfner. Stuttgart: Deutsche Verlags-Anstalt, 1999 .

Jastrow, Marcus. A Dictionary of the Targumim, The Talmud Babli and Yerushalmi, and the Midrashic Litarature. Peabody, MA: Hendrickson Publishers, 2005.

Klein, Gil P. "Torah in Triclinia: The Rabbinic Banquet and the Significance of Architecture." JQR 102 (2012): 325-70.

Lipiński, Edouard. "Le repas sacré à Qumrân et à Palmyre." ErIsr 20 (1989): 130*-34*.

McKenzie, Judith. The Architecture of Alexandria and Egypt c. 300 BC to AD 170. New Haven, CT: Yale University Press, 2007.

Maier, Johann. Die Tempelrolle vom Toten Meer und das “Neue Jerusalem." uтв 829. München: Ernst Reinhardt Verlag, 1997.

Milik, Józef T. “15. Description de la Jérusalem Nouvelle." Pages 184-193 in Les 'petites grottes' de Qumran. DJD 3. Oxford: Clarendon Press, 1962.

Pantel, Pauline S. La cité au banquet: Histoire des repas publics dans les cités grecques. Rome: L'École française de Rome, 1992. Repr. in Les Classiques de la Sorbonne 2, Paris: Publications de la Sorbonne, 2011.

Parry, Donald W., and Emanuel Tov, eds. The Dead Sea Scrolls Reader. Second Edition, Revised and Expanded. Vol. 1. Leiden: Brill, 2014.

Polybius. The Histories, Books 9-15. Translated by W. R. Paton, revised by F. W. Walbank Christian Habicht. LCL. Cambridge, MA: Harvard University Press, 2011.

Puech, Émile. Qumrân grotte 4.XXVII: Textes araméens, deuxième partie : 4Q550-575a, 580-587. DJD 37. Oxford: Clarendon Press, 2009.

Riethmüller, Jürgen. Asklepios: Heiligtümer und Kulte. 2 vols. Heidelberg: Verlag der Archäologie und Geschichte, 2005.

Roux, Georges. "Salles de banquets à Délos." Pages 525-54 in Études Déliennes. BCHSuppl 1. Paris, 1973.

Schiffman, Lawrence H. "Shelamim Sacrifices in the Temple Scroll." ErIsr 20 (1989): $176^{*}-83^{*}$.

Shimoff, Sandra R. "Banquets: The Limits of Hellenization." JSJ 27 (1996): 440-52.

Smith, Dennis E. From Symposium to Eucharist: The Banquet in the Early Christian World. Minneapolis, MN: Fortress Press, 2003.

Thackeray, Henry St. John. The Letter of Aristeas. London: SPCK, 1917. 